\title{
THE ADOPTION OF AGENCY BUSINESS ACTIVITY,
PRODUCT INNOVATION, AND PERFORMANCE IN CHINESE TECHNOLOGY VENTURES
}

\author{
HAIYANG LI*1 and KWAKU ATUAHENE-GIMA ${ }^{2}$ \\ ${ }^{1}$ Lowry Mays College and Graduate School of Business, Texas A\&M University, \\ College Station, Texas, U.S.A. \\ ${ }^{2}$ Department of Management, City University of Hong Kong, Kowloon, Hong Kong
}

\begin{abstract}
This study examines the roles of firm characteristics and environmental factors in the formation of interfirm alliances. Specifically, we examine the dual role of these groups of factors as inducements and opportunities for Chinese high-technology new ventures (HTNVs) in their adoption of agency business activity, a downstream type of alliance involving marketing and distribution of the products of foreign firms. Results suggest that both internal and external factors are related to the adoption of agency business activity but the inducement and opportunity value of environmental uncertainty may be dampened by institutional support provided to HTNVs. Further, we find that successful agency business activity is positively related to new venture performance but negatively related to its product innovation efforts. Theoretical and managerial implications are discussed. Copyright (C) 2002 John Wiley \& Sons, Ltd.
\end{abstract}

\section{INTRODUCTION}

Interfirm linkages or cooperative alliances have received considerable attention from strategic management researchers in recent years. Studies indicate that such alliances provide several benefits to firms including helping them to develop new technology and improve technical skills (Cohen and Levinthal, 1990; Dowling and McGee, 1994; Eisenhardt and Schoonhoven, 1996; Feeser and Willard, 1990; Zahra and Covin, 1993), learn new management skills (Ahuja, 2000; Kraatz, 1998) and develop innovative products (Grenadier and Weiss, 1997).

In parallel with the increased interest in interfirm alliances, scholars are paying attention to strategies of high-technology new ventures (HTNVs). Studies indicate that these firms face significant problems aptly termed 'liability of

Key words: agency business activity; product innovation; new technology ventures; China

*Correspondence to: H. Li, Lowry Mays College and Graduate School of Business, Texas A\&M University, College Station, TX 77843-4221 U.S.A. newness' by Stinchcombe (1965), including lack of adequate knowledge of their environments, new product development experience, as well as managerial and financial resources (Feeser and Willard, 1990; Shan, 1990; Zahra and Covin, 1993). Thus, they are highly vulnerable to environmental selection and have high failure rates with less than half of these firms lasting for 5 years (O'Shea and Stevens, 1998). Several studies have suggested that interfirm alliance is a potential strategy that HTNVs use to offset this liability of newness (Dowling and McGee, 1994; Eisenhardt and Schoonhoven, 1990). Empirical analysis of HTNVs in emerging technologies has found that alliances play an important role in their development of new products and technologies (Shan, 1990).

In general, two broad categories of explanations have been offered for firms' entry into interfirm alliances (Ahuja, 2000). The first suggests that firms enter into alliances to obtain access to needed resources, to learn new skills, and to enhance competitive parity (Eisenhardt and Schoonhoven, 1996; Kogut, 1988; Powell and Brantley, 1992; 
Varadarajan and Cunningham, 1995). Drawn on resource-based theory (Barney, 1991), this dominant view of alliance formation suggests that the need for resources acts as an inducement or incentive for firms to collaborate with other firms. The second category of explanation is the opportunity to collaborate perspective (Ahuja, 2000). This perspective suggests that the firm's ability to enter into alliances with other firms is determined by its ability to attract potential partners. Such ability is reflected in the resources and other potential advantages that the firm is capable of offering to potential alliance partners (Granovetter, 1985; Gulati, 1998; Kraatz, 1998; Shan, Walker, and Kogut, 1994; Stuart, 2000). In particular, researchers have emphasized the role of social capital and resources available through social network and institutional ties. For example, Eisenhardt and Schoonhoven (1996) found that large management teams have greater opportunity to form alliances because of their extensive social connections and relationships which offer opportunities for finding alliance partners or being found as an alliance partner. Ahuja (2000) suggested that alliance experience offers a core opportunity for firms to enter into new alliances.

While prior studies have advanced our understanding of the formation of interfirm linkages, several gaps remain. First, few studies have adopted the dual inducement-opportunity framework noted above in examining the formation of interfirm alliances. Moreover, they only provide a limited view of alliance formation. As noted by Ahuja (2000:318), 'any explanation of linkage formation behavior must account for the actor's inducement to form linkages and his/her opportunities to collaborate.' Second, most prior research has focused on established firms with only a few focusing attention on new ventures. Yet, new ventures play a significant role in economic and social development. In particular, the development of HTNVs is viewed as a revitalization tool for developed market economies and as a driver of economic transformation in transitional economies (Bruton and Rubanik, 1997; McDougall and Robinson, 1990; Zahra and Covin, 1993; Zhao and Aram, 1995). Yet, little research has examined the inducements and opportunities that these firms have in forming interfirm alliances. Indeed, this shortcoming in the literature is particularly true for new ventures in transitional economies.
Third, previous research on alliance formation among new ventures has focused primarily on the upstream activities of the value chain involving technology and new product development (Eisenhardt and Schoonhoven, 1996; Shan, 1990). Alliances that involve downstream activities of the value chain such as the adoption of agency business activity involving marketing and distribution of products of alliance partners has received limited attention. Compared to technology and product development alliances such downstream alliances involve lower risk. HTNVs in both developed and transitional economies adopt this strategy as a complement to their business activities. For example, companies such as Dell Computers serve as agents for others' products, in order to provide a more complete product line and accessories to customers. Wintak Technology, one of the fastgrowing Chinese computer companies, helps AST sell networking products and computers in China. Bruton and Rubanik (1997) observe that it is common for Russian HTNVs to import and wholesale the products of foreign firms.

Finally, we could not locate any study that has linked this type of alliance strategy with the product innovation and performance of HTNVs. Interfirm alliances are thought to influence product innovation and performance because they provide opportunities for resource acquisition, learning, and legitimacy (Dyer and Singh, 1998; Kraatz, 1998). However, empirical research evidence provides conflicting results (Kotabe and Swan, 1995). We believe that given the resource limitations of HTNVs and the potential attractiveness of agency business activity to these firms, the relationship between this strategy and product innovation and performance of these firms warrants systematic empirical research.

In this study, we contribute to the literature by examining the above gaps. Specifically, we follow the recent works of Ahuja (2000) and Eisenhardt and Schoonhoven (1996) by using the inducement-opportunities framework to examine both external and internal factors which drive the adoption of agency business activity by a sample of HTNVs in China. Formally, we define the adoption of agency business activity as an alliance strategy by which a firm markets and distributes a foreign firm's products and services. We further examine the relationship between the success of the agency business (defined as the proportion of a HTNV's sales attributable to the agency business 
activity) and new venture performance and product innovation efforts. In the next section, we develop hypotheses based on previous theory and research. This is followed by a discussion of the research design and methods. Next, research findings are presented and evaluated. Finally, managerial implications and directions for future research are explored.

\section{THEORETICAL BACKGROUND AND HYPOTHESES}

Several theoretical frameworks have been advanced to explain the motives underlying the entry of firms into alliances (Kogut, 1988; Varadarajan and Cunningham, 1995). The inducement-opportunities framework, which we adopt here, is informed by resource-based and social capital theories. The resource-based view suggests that firms are endowed with resources but do also need additional specific resources in order to compete effectively in particular markets (Barney, 1991). This need for resources is thought to be a major rationale behind alliance formation. Alliance formation provides tangible resources such as financial capital and technical skills, and intangible resources such as social position and market reputation (Dyer and Singh, 1998; Eisenhardt and Schoonhoven, 1996; Nahapiet and Ghoshal, 1998). On the other hand, firms' alliance formation is also related to their possession of resources, particularly those that are difficult for the partners to create on their own or obtain from the market (Ahuja, 2000). For example, the social capital resources held by firms may increase their attractiveness to potential partners and open opportunities for them to enter into alliances (Gulati, 1998).

In alliances between firms from transitional and developed economies, partners differ with respect to the specific resource needs that motivate the formation of the alliance. In general, resources of particular interest to firms from transitional economies include financial capital, technical and managerial capabilities and reputation, particularly that for quality (Hitt et al., 2000). This theoretical argument may be particularly relevant among HTNVs. Compared with large and established firms HTNVs tend to have relatively limited resources (McDougall and Robinson, 1990; Stinchcombe, 1965). Thus, an HTNV's inducement to enter into agency business activity can be ascribed to its need for resources (Shan, 1990). Through adopting such an activity, an HTNV may effectively manage its dependence on external environments (Pfeffer and Salancik, 1978). Like new ventures in other economies those in China have great difficulty in obtaining critical resources from the domestic market, particularly from banks and factor markets which are severely underdeveloped. For instance, only 3 percent of the 901 firms listed on the China stock exchange as of June 1999 were non-governmental firms such as HTNVs. Further, of the 300 billion RMB (approximately U.S. $\$ 38$ billion) loans granted by state banks to Chinese firms in 1998 only 5 percent were to non-governmental firms such as HTNVs (China Economic News, 2000). In addition, limitations with regard to the infrastructure (e.g., transportation and communication) in China create challenges for HTNVs' resource acquisition. This situation suggests that lack of resources could be related to the formation of agency business alliances by HTNVs in China.

Potential partners from developed market economies have particular interest in resources that include local market knowledge and access, and the social connections that would enable them to leverage their own resources. Hence, they tend to select alliance partners that have complementary and unique competences, local market knowledge and access as well as willingness to share such expertise (Hitt et al., 2000). It follows that a HTNV enters into agency business activity because it has resources needed by the foreign partners and can act proactively to respond to the resource needs of the partners. As Stuart (2000:793) argued, not all potential alliance partners are of equal value and those well-endowed firms 'are types of alliance partners that can produce the best ex post results for their associates.' For example, Eisenhardt and Schoonhoven (1996) found that alliances form when firms are in strong social positions such as when they are led by large, experienced, and wellconnected top management teams. Gulati (1995) found that previously allied firms were likely to engage in further alliances because they were familiar with each other in terms of goals, needs, skills, and capabilities. The possession of local knowledge and social capital may be of great significance in China, where social connections are critical facilitators of business activities.

With the above considerations in mind, we integrate the two theoretical perspectives and 
examine the relationship between external factors (environmental uncertainty, institutional support, and perceived industry growth) and internal factors (venture size, R\&D expenditure, and product development alliance) and the HTNV's adoption of agency business activity.

\section{External factors and the adoption of agency business activity}

Environmental uncertainty refers to the degree of uncertainty in terms of products, markets, and competitive behavior perceived by management of HTNVs in China. It has been viewed as the most relevant environmental characteristic that affects a firm's decision making (Dess and Beard, 1984; Downey, Hellriegel, and Slocum, 1975; Miller, 1987). From a resource-based perspective, when the market is uncertain and competitive, HTNVs become vulnerable to the external environment since they have difficulties in raising capital and other resources. In addition, an uncertain and competitive environment presents increased performance risk for HTNVs. Forming alliances with other firms provide a potentially viable means of dealing with such situations for several reasons. First, by increasing communication and information sharing agency business activity with foreign firms may mitigate the competitive intensity that HTNVs face. These alliances may enhance the learning and adaptive response of the HTNV (Kraatz, 1998) through handling foreign firms' products, customer interaction and feedback processes. Second, agency business activity focuses on the downstream activities (e.g., marketing and sales) in the value chain. Consequently, it may help HTNVs build their competencies and skills in marketing and distribution to support their own products.

Third, given environmental uncertainty, the adoption of agency business activity may not only provide Chinese HTNVs with tangible resources but also intangible resources such as reputation for quality and legitimacy in the Chinese market (cf. Nahapiet and Ghoshal, 1998). For example, given the relatively low level of technological sophistication in China, customers equate high quality with products of foreign firms. Thus, agency business activity may not only enhance the revenues of new ventures, but also their reputation for high-quality products. These arguments suggest that adoption of agency business activity could be a risk reduction strategy for HTNVs in comparison with product innovation. In the context of firms in transitional economies, Peng and Heath (1996) following North (1990) have advanced similar arguments for entry into interorganizational relationships. Eisenhardt and Schoonhoven (1996) argued that new ventures enter into alliances to enhance their legitimacy and therefore seek partners with strong intangible assets such as reputation. This motivation is likely to be strong for new ventures when the environment is uncertain. In a study of entrepreneurial firms in the biotechnology industry, Shan (1990) found that high environmental uncertainty was associated with alliance formation.

Foreign firms entering China may have particular concerns about the level of uncertainty in what is generally regarded as a highly complex and difficult to understand marketplace. Therefore, the uncertain Chinese market environment may not only act as an inducement for alliance formation but also as an opportunity for collaboration with the Chinese HTNVs. The logic for this proposition is that the high uncertainty of the Chinese environment and its cultural impediments offer significant challenges to would-be foreign market entrants. Hence, HTNVs in China become more valuable to potential foreign partners because they have already developed relationships with key stakeholders in the market and with key governmental agencies. These social relationships represent resources and capabilities that may be underutilized and therefore can be exploited through entry into agency business activity (Kraatz, 1998). Thus, for the foreign firm, the Chinese HTNVs have opportunity to leverage these social resources to lower the level of uncertainty and risk in marketing and distributing their products. Thus from both the inducement and opportunity perspectives, we posit that:

Hypothesis 1: Environmental uncertainty is related positively to the adoption of agency business activity by HTNVs in China.

\section{Moderating role of institutional support}

The above line of reasoning suggests that factors that ameliorate the resource constraints of the HTNVs may influence managerial perceptions of risks from environmental uncertainty such that its relationship with the firm's adoption of agency 
business activity may be weakened. One such factor is institutional support, which refers to the extent to which administrative institutions (e.g., government departments) provide initial and continuing financial, management, and technical support for HTNVs. The support provided by government institutions aims to help HTNVs conduct product and technology innovations because these firms are viewed as the window of the development in Chinese high-technology industries. Such support is important for HTNVs because they face significant problems in raising capital and other financial resources. This problem could be exacerbated for Chinese HTNVs in an uncertain environment because, as Simerly and Li (2000) have found, firms have limited potential for raising funds in uncertain environments. Hence, for these firms government financial support becomes an important, if not a prerequisite, means of obtaining capital and other resources (Nee, 1989). For example, a report by Beijing High-Technology Experimental Zone (BHEZ) Office (BHEZ Office, 1995) in China indicated that 76 percent of HTNVs within the Zone obtained initial funding from their administrative agencies.

The preceding arguments suggest that institutional support may alleviate the liability of newness of HTNVs and thus has impact on how managers of these firms frame the risks associated with environmental uncertainty. With higher institutional support these firms are likely to perceive the environment as less threatening to their firms' success and survival. This is likely to lower the inducement and opportunity value of environmental uncertainty in the adoption of agency business activity. Therefore, we posit that:

Hypothesis 2: The positive relationship between environmental uncertainty and the HTNVs' adoption of agency business activity is weaker when institutional support is higher.

Perceived industry growth is another environmental characteristic that may be related to the HTNVs' adoption of agency business activity. It refers to the degree of management perceived growth of their principal industry within the last 3 years or since founding (if the venture is less than 3 years old). Industry growth is an important indicator of industry structure, representing a key component of market attractiveness for new ventures (McDougall et al., 1994; Porter, 1980). As
Porter (1980) argues, in a rapid growth industry the entry of new ventures will provoke less retaliation by incumbent firms. Similarly, Miller and Camp (1985) suggest that high market growth can potentially reduce the effect of competitive pressures on new ventures. Thus, relative to the managers of HTNVs in low growth industries, those in high growth industries may not feel compelled to allocate resources into such activities as agency businesses given the significant potential for success in their core business of product innovation. Instead, they would rather like to reinvest their resources in long-term in-house product innovation to keep pace with changes in the industry (McDougall et al., 1994).

Industry growth also indicates environmental munificence: the extent to which the resources required by the firm are available in the market environment (Pfeffer and Salancik, 1978). Indeed, empirical research has found that venture capitalists prefer to invest in new ventures in high growth industries (MacMillan, Siegel, and Narasimha, 1985; Sandberg and Hofer, 1987). Thus, from the resource-based perspective, HTNVs are more likely to obtain resources from high growth industries than from low growth industries (Hannan and Freeman, 1977). When managers face high market growth at founding and expect this to continue, their ability to predict and obtain successful outcomes increases, thus reducing the incentive to enter into alliance relationships. This discussion suggests that higher perceived industry growth has less power in inducing the adoption of agency business activity. In support of these arguments Dickson and Weaver (1997) found that there is a greater tendency for firms to enter into alliance relationships when faced with low growth markets because managers become less certain of the future success of their firms in such environments. Eisenhardt and Schoonhoven (1996) also suggested that given the munificent conditions in high growth industries firms are less likely to form alliances because they have little need for resources that such alliances might bring.

Competing arguments to the above one can also be made. Firms in high growth industries might have greater need for resources and greater incentives to find new resources or to lever existing resources (e.g., lever links with customers, opportunities to learn related activities from a technologically superior partner rather than developing on its own). Thus, these firms might have a 
greater need to pursue alliances such as agency business activity. This would be particularly the case in China, where there are limited available resources for HTNVs. From the opportunity to collaborate perspective, high perceived industry growth might be highly attractive for undertaking agency business activities because foreign firms are attracted to high growth markets. For example, recent research suggests that industry attractiveness is a critical variable considered by firms from developed countries in choosing partners from emerging economies (Hitt et al., 2000). Thus perceived industry growth could be particularly fruitful for an HTNV with knowledge and networks in China, because the knowledge and networks provide a foundation for exploiting the opportunity open to foreign firms. Clearly, theoretical arguments can be made in support of both negative and positive relationships between perceived industry growth and the adoption of agency business activity. Given the lack of prior research in the context of our study, we offer the following competing hypotheses:

Hypothesis 3a: Perceived industry growth is related negatively to the adoption of agency business activity by HTNVs in China.

Hypothesis 3b: Perceived industry growth is related positively to the adoption of agency business activity by HTNVs in China.

\section{Internal factors and the adoption of agency business activity}

As discussed earlier, to enter into interfirm alliances HTNVs not only must have need for resources, they must also possess resources that are attractive to potential alliance partners (Ahuja, 2000; Eisenhardt and Schoonhoven, 1996). In this study we focus on internal factors such as venture size, R\&D expenditure, and product development alliance, because they reflect HTNVs' potential ability to provide value to potential alliance partners thus offering opportunities to collaborate.

\section{Venture size}

A venture's size reflects the availability of resources and therefore the firm's capacity to provide benefits to potential alliance partners. Social capital perspective suggests that large ventures have relatively sufficient resources, scale, and the social networks to provide value to their alliance partners (Hagedoorn and Schakenraad, 1994). It follows that larger HTNVs have more opportunity to attract and engage foreign firms for agency business activities than smaller ones. Some empirical findings support our argument. For example, Powell and Brantley (1992) and Gulati (1999) found that the frequency of interfirm cooperation is positively related to firm size. From the foreign firms' point of view, larger HTNV size may reflect greater social legitimacy and connections with the right administrative agencies as well as larger coverage of the Chinese market. Such social capital benefits associated with HTNVs' local connections are critical for foreign firms' success because connections (e.g., guanxi) are thought to be important substitutes for formal institutional support in China. Therefore, from an opportunity to collaborate perspective, venture size is probably related positively to HTNVs' adoption of agency business activity.

However, conflicting findings also exist. For example, Shan and his colleagues (Shan, 1990; Shan, Walker, and Kogut, 1994) found that larger firms are less likely to form cooperative relationships in commercializing new technology. From the resource-based theory viewpoint, this finding indicates that larger size reflects the availability of sufficient resources and therefore lowers the inducement to enter into alliances (Ahuja, 2000). It follows that larger HTNVs might be perceived to have less need for an agency alliance than smaller firms due to the possession of additional resources. Although both positions are plausible, in the current study there is substantial reason to believe that larger size demotivates alliance formation. The logic is that the prime objective of firms in a transitional economy for alliance formation is to acquire needed resources (Nee, 1989; Peng and Heath, 1996). Consequently, if large size reflects the availability of sufficient resources, it will be negatively related to the adoption of agency business activity.

Hypothesis 4: Venture size is related negatively to the adoption of agency business activity by HTNVs in China.

\section{$R \& D$ expenditure}

This construct is defined as HTNVs' investment in $\mathrm{R} \& \mathrm{D}$ as percentage of sales over the last 3 years 
or since founding (if it is less than 3 years old). $R \& D$ expenditure indicates the venture's ability to collaborate because it reflects its commitment to product innovation (Miller, 1987) and its technical competence and learning capacity (Cohen and Levinthal, 1990; Lane and Lubatkin, 1998). For foreign firms which attempt to enter into alliances, $\mathrm{R} \& \mathrm{D}$ expenditure represents a simple but manifest indication for them to assess the Chinese HTNVs' technical competence. Because of the technological complexity of the products for distribution, the HTNVs' technical competence is important in providing necessary technological and other support services for products involved in the agency activity. Foreign firms are likely to select as agents HTNVs which have commitment to R\&D and are capable of providing value-added distribution services. Consistent with these arguments, Hitt et al. (2000) found that firms from developed countries consider the capability for quality of potential alliance partners from emerging economies as a critical selection variable. Similarly, our interviews with several Chinese HTNVs suggest that to be successful agents HTNVs have to cooperate closely with the foreign product suppliers in product application solutions, technical training, and maintenance services. The lack of ability to cooperate may increase the probability that the new venture will be unable to find alliance partners. For this reason, technical skills and expertise developed through $R \& D$ investments could induce the firm to enter into an alliance formation in order to leverage the technical capabilities of the foreign alliance partner (Hitt et al., 2000).

Thus, high R\&D expenditures suggest both an inducement and opportunity for these firms to enter into agency business activities. These arguments are consistent with Stuart's (1998) finding that high-technology firms tend to form alliances when they have a track record of developing new products. Hence:

Hypothesis 5: The level of $R \& D$ expenditure is related positively to the adoption of agency business activity by HTNVs.

\section{Product development alliance}

A firm's involvement/experience in alliances and/ or its accumulated learning from its past alliances are expected to relate to its alliance formation.
For example, Gulati (1999) found that participation in alliances is influential in the firm's decision to enter into new alliances. Although there are many types of alliances, in this study we focus on product development alliance, defined as HTNVs' involvement/experience in joint development, manufacturing, and marketing new products with other firms. Unlike the adoption of agency business activities which concern only the downstream activities (e.g., importing and selling of products already developed by foreign firms), product development alliance involves joint actions by the HTNV and its partners to develop and sell a new product. Thus, it involves both the upstream and downstream activities of the value chain (cf. Bucklin and Sengupta, 1993; Magrath, 1992). Such an alliance is not part of the agency business activity. Further, product development alliance irrespective of the type of product, technology, market, or the firm involved may have implications for the HNTV's decision to adopt agency business activity.

HTNVs' involvement in a product development alliance provides an opportunity for entry into agency business activity because it signals their experience and reliability in collaborative behavior to potential alliance partners (Ahuja, 2000; Gulati, 1999). Product development alliances may take on a more substantive role in alliance formation in China, given the lower level of technological capability of most firms in comparison with those in the West. It may provide Chinese HTNVs the necessary legitimacy, reputation, and expertise for successful engagement in alliances to foreign firms. Thus, HTNVs' experience of product development alliance serves as differentiating capability that is likely to be of value to foreign firms when they assess potential agency business partners. From a social network perspective, the HTNVs' involvement in such an alliance provides evaluative information on their collaboration opportunities, capabilities, and likely behavior to potential foreign alliance partners, thus lowering their perceived risk associated with alliance formation with the HTNVs (cf. Ahuja, 2000). Further, we argue that Chinese HTNVs' product development alliance with another firm provides them with an enhanced opportunity to enter into agency business activity because it provides them with access to information about a larger number of firms who may be potential alliance partners (Eisenhardt and Schoonhoven, 1996). 
From an inducement perspective, product development alliance may also be related positively to the adoption of agency business activity because the knowledge and experience HTNVs gain in such alliances open their eyes to the need for accessing the knowledge and information of other firms. For example, Powell, Koput and Smith-Doerr (1996) found that $R \& D$ alliance is related positively to new alliance formation with suppliers. Hence:

Hypothesis 6: Product development alliance is related positively to the adoption of agency business activity by HTNVs.

\section{Successful agency business activity, new venture performance and product innovation}

The above discussion focuses on both external and internal factors as inducements and opportunities for HTNVs' adoption of agency business activity. In this section we examine the relationship between successful agency business activity (as measured by the proportion of an HTNV's sales attributable to the agency business activity) and new venture performance and product innovation efforts. Given the highly competitive and uncertain market environment in China, we contend that successful agency business activity is positively related to the overall performance of the new venture for three reasons. First, the adoption of agency business activity represents a risk reduction strategy. Marketing and distributing the products and services of foreign firms entail less risk than internal product development. Risk can be further reduced via the enhanced reputation and legitimacy effects associated with success in selling the products of well-known foreign firms. As Stuart, Hoang, and Hybels (1999) empirically demonstrated, new ventures can benefit from prominent partners because of the transfer of status through interorganizational networks. The transfer of status from foreign firms may reduce the risk perceived by the market in dealing with the HTNVs. Second, the adoption of agency business provides opportunities for learning from alliance partners (Granovetter, 1985; Kraatz, 1998). Thus, by successfully distributing products for foreign firms, HTNVs in China obtain access to management and marketing skills that can contribute to the market performance of their own products. Third, empirical evidence has shown that distributing products for international firms is a profitable business activity for new ventures (Bruton and Rubanik, 1997). Therefore, we argue that success with agency business activity will be positively related to the overall performance of the HTNVs measured by both subjective and objective measures.

Hypothesis 7: Successful agency business activity is related positively to HTNVs' performance.

Successful agency business activity may also be related to the HTNVs' product innovation efforts. From an organizational learning perspective it can be argued that the adoption of agency business activity provides an avenue for HTNVs to learn about new technology and management skills that could improve their technical capabilities (Cohen and Levinthal, 1990; Granovetter, 1985; Kraatz, 1998; Lane and Lubatkin, 1998). The products distributed by HTNVs for the foreign firms are usually considered innovative in the Chinese market. Though these products are not developed by HTNVs, they nevertheless provide them with a learning platform for their own innovative efforts (Grenadier and Weiss, 1997). Technical experience and skills gained through marketing and servicing technology products of foreign firms may also enhance the absorptive capacity of HTNVs (Cohen and Levinthal, 1990; Kogut and Zander, 1992). In addition, agency business activity may provide extra resources that may encourage experimentation and learning (Bourgeois, 1981; Cyert and March, 1963). Therefore, we posit that HTNVs with higher proportion of agency business activity are more likely to pursue product innovation with increased vigor.

Hypothesis 8: Successful agency business activity is related positively to HTNVs' product innovation.

\section{RESEARCH METHODOLOGY}

\section{Sample and data collection}

This study examined ventures from high-technology industries located in BHEZ, one of the largest high-tech experimental zones in China. Firms in this zone were chosen because they are among the fastest-growing high-technology firms in China (BHEZ Office, 1995). We randomly selected 300 ventures from a list provided by 
BHEZ Office. All selected ventures were no more than 8 years old. This was consistent with prior research that chose the 8 years cut-off for defining new ventures (e.g., McDougall et al., 1994; Miller and Camp, 1985).

A letter was sent to the general managers of the sampled ventures. It explained the purpose of the study and invited their participation in the study. We contacted by phone those firms that agreed to participate to ensure that the potential respondents were qualified and were committed to cooperate in the research (Feeser and Willard, 1990). As a result of these efforts, 202 of 300 ventures were deemed suitable to participate in the study.

We adopted a face-to-face interview method for data collection in order to improve the response rate (Pearce, 1983). Based on our past research experience and the pilot study, we were convinced that respondents were more likely to provide valid information with this method. Indeed, this method of data collection is thought to be better than traditional mail surveys in emerging economies because it offers a chance for the researchers to clarify questions, and to check and probe aspects of behavior (Hoskisson et al., 2000). Further, the interviews offered respondents an opportunity to ask for clarification to enhance their understanding of the issues under study.

The questionnaire for the interview survey was originally prepared in English and then translated into Chinese by two management researchers competent in both languages and with substantial research experience in the subject area in China. To avoid cultural bias and ensure validity, the Chinese version was then back-translated into English. We paid special attention to any misunderstanding likely to result from the translations. The instrument was then pretested with 8 founders and 15 senior managers from 10 ventures. Using input from the pretest we revised the survey instrument to improve the clarity and relevance of the questionnaire, and to ensure that questions were interpreted as expected. To further test the reliability and validity of the measures, the questionnaire was then subjected to a pilot study with a sample of 80 new ventures from a city located in the southeast of China. Results of this pilot study indicated that measures loaded strongly on their corresponding constructs and showed an acceptable level of reliability. Our detailed work on back-translation and in-depth discussion with founders and senior managers, coupled with the results of the pilot test, assure our confidence in the general appropriateness of the instrument and data collection method.

For data collection, we adopted the key informant approach. The underlying assumption of the key informant approach is that the person, by virtue of his/her position in the organization's hierarchy, is able to provide opinions and perceptions that are valid reflections of those of other key decision-makers in the firm (Phillips, 1981). While the ideal may be to use multiple informants, a single informant approach could be the source of needed information for new ventures of relatively small size (Phillips, 1981). In addition, our pilot test suggested that a multiple-informant approach could be very expensive in China. Nonetheless, in 45 cases, we obtained data from two informants as a validation sample. We categorized these informants into two groups: $\mathrm{CEO} /$ general manager and senior managers (such as marketing or business development managers). We conducted a series of $t$-tests to determine if there were any differences among the responses of the two groups on each of our constructs and found no statistically significant differences.

We further checked the validity of the informants' responses in two ways. First, the informants were asked to indicate the level of knowledge and the extent of their involvement in making strategic decisions of their firms (Conant, Mokwa, and Varadarajan, 1990). The means of the level of knowledge and the extent of involvement were 7.18 and 7.09 respectively on a 9-point Likert scale, indicating that the informants were likely to be knowledgeable about the issues under study. Second, the informants were asked to indicate their industrial working experience (Phillips, 1981). The average working experience was 7.8 years, suggesting that the selected informants were experienced and knowledgeable about their ventures' industry. The results from the subsample with multiple informants along with high involvement and knowledge of our key informants increased our confidence in the quality and accuracy of our data.

We received 202 completed questionnaires but 18 were excluded from the analysis because of missing values. Thus, the effective participation rate was 61.3 percent $(184 / 300)$. Of the participating ventures, 50.5 percent were in the electronic information industry (such as computers, software development, information technology, consumer electronics), 17 percent in integrated opticalmechanical and electric products, 12.6 percent in 
new energy and new materials, 10.4 percent in new pharmaceutical and bioengineering, and 9.3 percent were classified as others (e.g., scientific instruments, aerospace technology). This distribution is consistent with that published by the BHEZ Office (1995), which indicates an industry distribution of 47.9 percent, 20.1 percent, 13.1 percent, 9.3 percent, and 9.6 percent, respectively. We viewed this consistency as evidence that the sample was representative of the types of the firms that were in the BHEZ. In addition, we compared the responding firms with those of nonrespondents and found no statistically significant differences in terms of size $(F=0.98, p>0.10)$ and age $(F=0.23$, $p>0.10)$. The mean age of the sampled firms was 4.83 years (S.D. 2.3) with 29 percent of the ventures being 3 years old or less, 38 percent between 4 and 5 years old and 33 percent between 6 and 8 years old.

\section{Measures}

We followed guidelines generally associated with proper retrospective data collection in order to ensure the accuracy and validity of the data collected (Miller, Cardinal, and Glick, 1997). We restricted the recall time frame to 3 years (or since their founding for those firms less than 3 years old). A 3-year or less time frame was chosen not only to ensure we do not place an undue recall burden on respondents but also because it seemed an appropriate time frame for negotiation and implementation of agency business activity. Previous studies of technology development alliances which involve greater technical knowledge development than agency business activity use a 3- to 5-year time frame (e.g., Ahuja, 2000; Stuart, 1998). We interviewed top/senior managers who were directly involved in the firms' strategic decision making. We assured all respondents of confidentiality. We also provided a full explanation of the usefulness of the project for the respondents' organizations, and offered an incentive (i.e., summary of the results) to foster a sense that the respondents would benefit from involvement in the study. Adler, Campbell, and Laurent (1989) noted that respondents in China are likely to answer questions based on the way they want their firms ideally to be, not the way they actually are. Thus, we asked the respondents to base their responses on the real situation in their firms. Finally, prior research has raised concerns about social desirability aspects of responses in the Chinese context (Adler et al., 1989). This concern seems likely to be exacerbated by the on-site interview approach to administering the questionnaire because of the great importance attached to face in the Chinese context. To minimize social desirability bias, the respondents were repeatedly reminded that there were no right or wrong answers to the questions being asked of them (e.g., Miller et al., 1997). Also, we deleted 18 cases from the analysis due to missing data. These, coupled with the fact that we obtained objective performance data from only 59 ventures, suggest that problems of social desirability as well as any pressure on the participants associated with our interview method could be considered as minimal.

\section{Dependent variables}

To measure the adoption of agency business activity we asked the respondent to indicate whether his/her firm was currently involved in any business as an agent for a foreign firm. The construct was dummy coded $(0=$ No and $1=$ Yes $)$. We validated this measure using the sample with two informants as discussed previously. A crosscheck showed that in all 45 cases the two informants were consistent in indicating their firms' adoption of agency business activity. Successful agency business activity was measured by the average percentage of the firm's total sales attributable to the agency business for the past 3 years or since its inception if the venture was less than 3 years old.

New venture performance was measured with both subjective and objective items. Subjective measures were used because prior research has provided substantial evidence supporting the reliability and validity of perceptual performance measures (Geringer and Hebert, 1991; Dess and Robinson, 1984). Indeed, McDougall et al. (1994) suggest that in the new venture setting a more complete picture of performance may be obtained by using subjective measures of performance. We used four market-related indicators to measure this construct: sales growth rate, market share growth, cash flow from market operations, and the firm's overall reputation. The respondents were asked to indicate how successfully their venture has achieved these goals relative to its established goals over the past 3 years on 5-point Likert scales. To obtain an objective measure of new venture performance, respondents were asked to indicate 
the sales growth rate (\%) of their firms for each of the past 3 years or since its founding if the firm was less than 3 years old. We obtained data from 59 ventures. The average sales growth was calculated for analysis. This more objective measure was significantly related to the subjective measure of new venture performance $(r=0.36, p<0.01)$. Product innovation was measured with four items drawn from Miller (1987) and Zahra and Covin (1993). The respondent was asked to compare his/her venture with its major competitors and then indicate the extent to which the venture engaged in developing and launching its own new products.

\section{Independent variables}

We measured environmental uncertainty by four items drawn from the studies by Miller (1987), reflecting the degree of price, product, technological, and competitive change as perceived by HTNVs in their principal industries. To measure institutional support we used five newly developed items reflecting the role of government in providing financial, technology information, and manufacturing support to the ventures (BHEZ Office, 1995). We measured perceived industry growth by three items drawn from the work of McDougall et al. (1994) reflecting the growth in demand and attractiveness of the industry. Following previous research (e.g., Shan, 1990) we used the number of full-time employees to measure venture size. We transformed this measure by natural log because it is expected that the effect of size would increase at a diminishing rate. $R \& D$ expenditure as percent of sales was measured by the average percentage of sales spent on R\&D over the past 3 years or since founding if the venture was less than 3 years old. We measured product development alliance by six items based on the work of Bucklin and Sengupta (1993) and Magrath (1992) and our field interviews. These measures assessed the focal venture's cooperation with other firms in the new product development process including designing, manufacturing and marketing of new products.

\section{Control variables}

In testing the hypotheses, several demographic variables were controlled for because they may affect new ventures' strategy making and performance (McCann, 1991; Zahra, 1993). For venture ownership, state- and collectively owned ventures form one category while privately owned and joint ventures form a second category. The reason for binary categorization is that state- and collectively owned firms in China operate under different regulatory conditions from privately owned and joint ventures (Nee, 1989). Venture age was used as a continuous variable. We measured the number of years since its founding, with the upper limit being 8 years. Venture origin was classified into two categories: independent ventures (which are established by independent entrepreneurs) and corporate ventures (which are founded and supported by established companies, e.g., joint ventures). They were dummy coded as 0 and 1 respectively. Industry type was also controlled for with electronic information industry coded as 0 and all others coded as 1 . This binary classification follows the practice of the BEZ, which lumps computer manufacturing, information technology, software development, and electronics into one category as electronic information industry, separate from all other ventures. Because of the limited sample size, we did not use the multiple industry categories approach (e.g., coded as dummies for each). Also because over half of the sample is from the electronic information industry, it is meaningful to control for this potential industry effect.

To test the hypotheses regarding how the proportion of agency business activity relates to new venture performance and product innovation, the above demographic variables were also controlled for. Further, environmental uncertainty and perceived industry growth were included as controls because of their potential impact on product innovation and new venture performance (Eisenhardt and Schoonhoven, 1990; McDougall et al., 1994). Given the potential confounding effect between the agency business activity and product development alliance, the latter was controlled for. We also controlled for relatedness of agency business activity with the venture's own business because such relatedness may affect the ease of transferability of core skills and economies of scale and scope (Rumelt, 1974). We measured this construct with a single item by asking respondents to indicate the extent to which the products they are marketing and distributing for foreign firms are related to the venture's own products.

\section{Measurement validation}

We used a multistage process to assess construct validity with the guidelines outlined by Anderson 
and Gerbing (1988). We first examined item-tototal correlations and performed an exploratory factor analysis for each scale since the measures had been modified from previous studies. Then, we conducted confirmatory factor analysis to test for the unidimensionality and convergent validity of the constructs. Because of the sample size and the number of items, we divided the constructs into two subsets of theoretically related groups. The scale items, along with factor loadings and fit statistics, are provided in Table 1. As the results show, the standardized loadings are highly significant for all the items, suggesting that all of these indicators are similarly responsive to changes in the underlying constructs they are purported to measure (one item from institutional support was deleted because of its lower level of factor loading). Moreover, the fit indices for each model suggest that the models fit the data very well, providing further evidence of convergent validity.

Next, we assessed discriminant validity of the constructs by testing if correlations between any two constructs were significantly different from unity. This required a comparison between two models in which one was constrained with the correlation equal to one and another was not. In each case discriminant validity was evidenced by the statistically significant chi-square difference between the models. For example, the comparison involving product innovation and product development alliance provided a $\chi^{2}(1)=179.02(p<$ $0.01)$, suggesting that these measures are distinct (results of this analysis are available upon request).

Finally, we assessed the reliability of the constructs with Cronbach's coefficient alpha. All scales except one have reliabilities greater than 0.70 . The alpha for competitive intensity is 0.60 , which is generally acceptable for questionnaire scales. Considering the face validity of this factor and the strong factor loadings, we believed that it was reasonable to use this factor in the subsequent analyses. Table 2 presents means, standard deviations, and correlations for the constructs.

\section{ANALYSIS AND RESULTS}

\section{The adoption of agency business activity}

We used logistic regression to test the relationship between external and internal factors and the adoption of agency business activity by HTNVs. Logistic regression restricts the range of the dependent variable to a value between 0 and 1 , which is appropriate for investigating the likelihood or probability of the adoption of agency business activity. The general specification is as follows: $\log \{\mathrm{P}(\mathrm{Y}=1) /(1-P(\mathrm{Y}=1)\}=\mathrm{B}(\mathrm{X}, \mathrm{M})$, where $\mathrm{P}(\mathrm{Y}=1)$ is the probability that a venture adopts agency business activity and $\mathrm{X}$ and $\mathrm{M}$ are vectors of independent and control variables.

Note that to test the interaction effect as indicated in Hypothesis 2 we entered the cross-product of institutional support and environmental uncertainty into the logistic model. Table 3 presents the results of logistic regression analysis that tests the relationship between environmental variables and the probability of agency business adoption by HTNVs. The model $\chi^{2}$ is statistically significant, indicating that the predictor variables are related significantly to the dependent variable, the adoption of agency business activity.

Hypothesis 1 states that environmental uncertainty is related positively to the adoption of agency business activity. The results presented in Table 3 support this hypothesis. The significantly negative relationship between the crossproduct of environmental uncertainty and institutional support and the adoption of agency business activity lends support to Hypothesis 2. This suggests that institutional support weakens the power of environmental uncertainty as an inducement or opportunity for new ventures to enter into agency business activity. Perceived industry growth has a significantly negative relationship with the adoption of agency business activity, which provides support for Hypothesis 3a. In other words, our results do not support the alternative argument in Hypothesis $3 \mathrm{~b}$ that perceived industry growth may act as an opportunity for HTNVs to enter into agency business activity to leverage their resources to exploit the available growth opportunities.

The results suggest a negative relationship between venture size and the adoption of agency business activity. This finding supports Hypothesis 4 stating that new ventures may need resources and may therefore enter into alliances to obtain such resources. In other words, our results do not support the alternative viewpoint that alliance formation offers opportunities for larger new ventures to leverage available resources. Hypothesis 5 stating that $R \& D$ expenditure as percent of sales is 
Table 1. Construct measurement and confirmatory factor analysis by LISREL

\begin{tabular}{lcc}
\hline Item description summary & $\begin{array}{c}\text { Standardized } \\
\text { loading }\end{array}$ & $t$-value \\
\hline
\end{tabular}

\section{Constructs in Model 1}

Environmental uncertainty $(\alpha=0.60)$

Rate the degree to which each of these statements describes your principal industry over the last 3 years: ${ }^{\mathrm{a}}$

1. the competitive intensity has been very high and uncertain

2. severe price competition has been a characteristic of my industry

3. our firm must change its marketing practices frequently to keep up with the market and competitors

4. the rate at which products or services become obsolete has dramatically increased

Perceived industry growth $(\alpha=0.75)$

Rate the degree to which each of these statements describes your principal industry over the last 3 years:

1. there has been high growth in demand in this industry

2. this industry offered many attractive opportunities for future growth

3 . growth opportunities in this industry have been abundant

Institutional support $(\alpha=0.77)$

Please indicate the extent to which in the last 3 years government and its agencies have:

1. implemented policies and programs that have been beneficial to your venture's operations

2. provided needed technology information and other technical support for your venture

3. played a significant role in providing financial support for your venture

4. helped your venture to obtain licenses for import of technology, manufacturing and raw material, and other equipment

5. seldom interfered in the operations of your venture ${ }^{\mathrm{b}}$

Model Fit Index

$\chi^{2}=101.26(p=0.00), \mathrm{GFI}=0.90, \mathrm{RMSEA}=0.08, \mathrm{NNFI}=0.92$, $\mathrm{CFI}=0.92$

\section{Constructs in Model 2}

Product innovation $(\alpha=0.83)$

Rate your venture relative to its major competitors over the last 3 years the extent to which it has:

1. placed significant emphasis on new product development through allocation of substantial financial resources

2. developed a large variety of new products or made dramatic changes in existing products

3. increased the rate of new product introductions to the market

4. increased its overall commitment to develop and market new products

Product development alliance $(\alpha=0.86)$

To what extent do these statements describe your firm over the last 3 years relative to your competitors?

1. marketed complementary new products with other firms

2. introduced new products jointly with other firms

3. promoted new product lines jointly with other firms

4. jointly distributed and provided new product support services with other firms

5. jointly designed and manufactured new products with other firms

$0.75 \quad 10.28$

6. established cooperative pricing agreements with other firms for R\&D

$0.73 \quad 10.64$

$0.59 \quad 8.20$ 
Table 1. (Continued)

New venture performance $(\alpha=0.78)$

Indicate how successfully your venture has achieved these goals in the last three years:

1. sales growth rate

2. market share growth

3. cash flow from market operations

4. firm reputation

0.74

0.81

0.57

0.70

Model fit Index

$\chi^{2}=156.73(p=0.00)$, GFI $=0.90$, RMSEA $=0.06, \mathrm{NNFI}=0.92$, $\mathrm{CFI}=0.93$

${ }^{a}$ For new ventures that were less than 3 years old the response time frame was since their founding.

${ }^{\mathrm{b}}$ Items were deleted because of low item-to-total correlations.

positively related to the adoption of agency business activity is not supported, although the sign is in the predicted direction. In support of Hypothesis 6 , product development alliance has a significant positive relationship with the adoption of agency business activity indicating the potential social capital opportunities for alliance formation derived from such an alliance.

\section{Successful agency business activity, new venture performance, and product innovation}

We used ordinary least squares regression analysis to examine the relationship between successful agency business activity, new venture performance, and product innovation. These analyses involved only those ventures that had adopted agency business activity $(n=106)$. Table 4 presents the results.

In Model 1a, we tested the relationship between successful agency business activity and new venture performance measured with subjective measures. The results show that successful agency business activity has a significantly positive relationship with new venture performance, thereby supporting Hypothesis 7. Note that product innovation is also related positively to new venture performance. As a sensitivity analysis, in Model $1 \mathrm{~b}$ we replaced the subjective measure with the objective measure of new venture performance. Although the sample is small, as the data in Table 4 indicate, with this alternative measure, we still obtained a similar pattern of results described above with respect to subjective measure of new venture performance. These findings appear to lend some support for the assertion that the adoption of agency business activity is related to the performance of HTNVs (Bruton and Rubanik, 1997).
In Model 2, we tested the relationship between the success of the agency business activity and product innovation. Results show that successful agency business activity has a significantly negative relationship with product innovation. Thus Hypothesis 8 is refuted. A possible reason is that a greater success with the agency business activity could lure managers of HTNVs into failing to develop in-house product innovation programs because competences in the downstream activities involved in agency business activity as well as competencies in developing the associated network ties with foreign firms may be perceived as easier to negotiate and leverage than in-house product innovation activity. Successful agency business activity could also lead to changes in the goals and aspirations of managers such that a conscious strategic choice is made to focus on this activity rather than on product innovation (Cyert and March, 1963). It may also be argued that failure in achieving strong product innovation inhibits a firm's ability to attract foreign firms for whom the HTNV could serve as an agent.

Two control variables-perceived industry growth and product development alliance-are positively related to product innovation. The latter finding suggests that an interfirm alliance that spans the entire value chain ranging from product design to marketing is more likely to be related to product innovation than agency business activity that involves only the downstream aspects of the value chain. Interestingly, we found that relatedness of agency business activity with the HTNV's markets and products is positively related to new venture performance measured by objective items. This finding is in keeping with the argument that related businesses may be more beneficial to the firm than is unrelated business because of the 


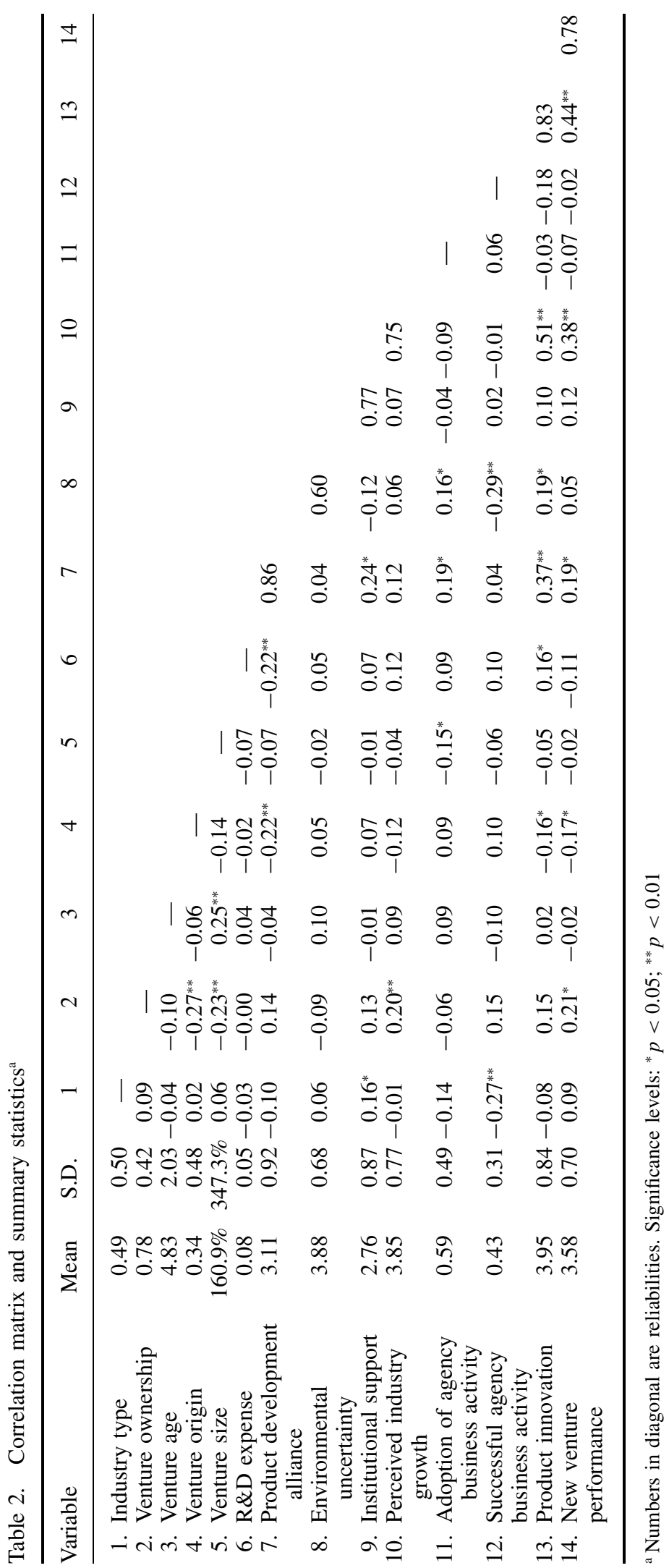


Table 3. The adoption of agency business activity: logistic regression analysis

\begin{tabular}{|c|c|c|}
\hline Variables & $B$ & Wald $\chi^{2}$ \\
\hline \multicolumn{3}{|l|}{ Control variables } \\
\hline Industry type & 0.16 & 0.13 \\
\hline Venture ownership & -0.70 & 1.27 \\
\hline Venture age & 0.12 & 1.17 \\
\hline Venture origin & 0.35 & 0.47 \\
\hline \multicolumn{3}{|l|}{ Independent variables } \\
\hline $\begin{array}{l}\text { Environmental } \\
\text { uncertainty }\end{array}$ & $0.75^{*}$ & 4.70 \\
\hline Institutional support & -0.19 & 0.48 \\
\hline $\begin{array}{l}\text { Environmental } \\
\text { uncertainty } \times \\
\text { institutional support }\end{array}$ & $-0.96^{*}$ & 4.10 \\
\hline $\begin{array}{l}\text { Perceived industry } \\
\text { growth }\end{array}$ & $-0.71^{*}$ & 4.87 \\
\hline Venture size & $-0.38^{*}$ & 4.26 \\
\hline $\begin{array}{l}\text { R\&D expenditure as } \\
\text { percentage of sales } \\
\text { turnover }\end{array}$ & 1.24 & 1.21 \\
\hline $\begin{array}{l}\text { Product development } \\
\text { alliance }\end{array}$ & $0.53^{*}$ & 4.27 \\
\hline Constant & 0.48 & 0.06 \\
\hline Model $\chi^{2}$ & $24.06^{*}$ & \\
\hline $\begin{array}{l}\Delta \chi^{2} \text { with the entry of } \\
\text { interaction term }\end{array}$ & $5.40^{*}$ & \\
\hline d.f. & 11 & \\
\hline$N$ & 184 & \\
\hline
\end{tabular}

Significance level (two-tailed): ${ }^{*} p<0.05$

ease of transferability of core skills and economies of scale and scope (Rumelt, 1974; Teece, 1980).

\section{DISCUSSION AND IMPLICATIONS}

Resource-based and social network theories have confirmed the importance of interfirm relationships for individual firms' capabilities and success in uncertain environments. There has been a significant amount of research on interfirm alliances based on these theories, particularly those involving technology development alliances and between established firms. In this study we contribute to this stream of research by examining the factors that act as inducements or opportunities for technology new ventures to enter into downstream alliances involving marketing and distribution. Particularly, we focused on the adoption of agency business activity as an interfirm alliance between HTNVs in China and foreign firms and examined its links with internal firm characteristics and external environmental factors. We also explored its performance and product innovation implications.

Our findings provide some support of our theoretical arguments that external and internal factors may act as inducements and opportunities for HTNVs in China to enter into agency business activity with foreign firms. First, our results suggest that environmental uncertainty is positively related to the adoption of agency business activity. This finding provides support for the resourcebased view that HTNVs have problems raising capital and other resources in an uncertain environment and therefore may enter into alliances in such an environment. In other words, when there is a need for resources an uncertain environment appears to act as an inducement for alliance formation. The same finding appears to support the opportunity to collaborate perspective, if viewed from the viewpoint of the foreign firms entering China. These firms place significant emphasis on unique competencies, market knowledge, and market access in selecting partners from emerging markets (Hitt et al., 2000). These selection criteria may become even more important when the environment is uncertain. Hence, environmental uncertainty appears to provide an alliance formation opportunity for HTNVs in China because their market knowledge and other unique competencies in the Chinese market are prime resources required by foreign firms to reduce their risks in entering the market.

However, the relationship between environmental uncertainty and the adoption of agency business activity is moderated by institutional support such that when institutional support is high environmental uncertainty is negatively related to the venture's adoption of agency business activity. It seems that institutional support may lower managerial perceptions of environmental risk facing HTNVs. This reduces the inducement and opportunity to enter into alliances as a coping mechanism against environmental uncertainty.

The second group of findings is that perceived industry growth and venture size are negatively related to the adoption of agency business activity. The former finding is similar to Eisenhardt and Schoonhoven's (1996) argument that munificent market conditions are related negatively to alliance formation. The latter finding is consistent with previous research results that the linkage between alliance formation and firm financial assets is weak at best (Gulati, 1999). From the resource-based 
Table 4. Successful agency business activity, product innovation and new venture performance (standardized regression coefficients)

\begin{tabular}{|c|c|c|c|}
\hline Variables & $\begin{array}{c}\text { Model 1a } \\
\text { New venture } \\
\text { performance }\end{array}$ & $\begin{array}{c}\text { Model 1b } \\
\text { New venture } \\
\text { performance }\end{array}$ & $\begin{array}{c}\text { Model } 2 \\
\text { Product } \\
\text { innovation }\end{array}$ \\
\hline \multicolumn{4}{|l|}{ Control variables } \\
\hline Industry type & $0.20^{*}$ & 0.09 & -0.15 \\
\hline Venture ownership & -0.14 & $-0.27^{* *}$ & 0.11 \\
\hline Venture age & 0.01 & -0.09 & -0.10 \\
\hline Venture size & 0.08 & 0.12 & -0.01 \\
\hline Venture origin & -0.09 & 0.04 & 0.08 \\
\hline $\begin{array}{l}\text { Environmental } \\
\text { uncertainty }\end{array}$ & 0.05 & 0.05 & 0.12 \\
\hline $\begin{array}{l}\text { Perceived industry } \\
\text { growth }\end{array}$ & $0.16^{*}$ & 0.02 & $0.37^{* * *}$ \\
\hline $\begin{array}{l}\text { Product development } \\
\text { alliance }\end{array}$ & -0.12 & $-0.44^{* * *}$ & $0.42^{* * *}$ \\
\hline $\begin{array}{l}\text { Relatedness of agency } \\
\text { business }\end{array}$ & 0.09 & $0.25^{* *}$ & -0.04 \\
\hline \multicolumn{4}{|l|}{ Independent variables } \\
\hline $\begin{array}{l}\text { Successful agency } \\
\text { business activity }\end{array}$ & $0.29^{* *}$ & $0.32^{* * *}$ & $-0.25^{* *}$ \\
\hline Product innovation & $0.51^{* * *}$ & $0.49^{* * *}$ & \\
\hline$R^{2}$ & 0.31 & 0.75 & 0.44 \\
\hline Adjusted $R^{2}$ & 0.18 & 0.65 & 0.37 \\
\hline d.f. & $11 / 55$ & $11 / 27$ & $10 / 73$ \\
\hline$F$-value & $2.30^{* *}$ & $7.46^{* * *}$ & $5.84^{* * *}$ \\
\hline
\end{tabular}

Significance levels (two-tailed): ${ }^{*} p<0.10,{ }^{* *} p<0.05,{ }^{* * *} p<0.01$.

view of the firm, these findings suggest that given munificent environment and strong financial assets, larger Chinese HTNVs are unlikely to enter into agency business activity. It may be that small HTNVs have relatively fewer internal resources and thus have greater propensity to engage in agency business activity in order to spread their risks (Teece, 1980). In addition small firms may adopt agency business activity in order to offer a fuller line of products - something difficult to do through internal offerings - with economic efficiency. In contrast, larger firms may have less need to do so because they are more likely to have a broad enough line of their own. The implication of these results is that the opportunities for alliance formation provided by industry growth and availability of resources from larger size are not utilized by Chinese HTNVs. In other words, when alternative sources of resource are not lacking, HTNVs tend not to seek network relationships with foreign firms (e.g., MNCs). In this sense, by not using the growth market and size to attract alliance partners Chinese HTNVs in our sample are not tapping all the available opportunities for growth through alliance formation.

The third major finding of our study concerns the positive relationship between the adoption of agency business activity and product development alliance. The finding supports the argument that social capital is important for HTNVs' alliance formation, reinforcing the recent finding that foreign firms consider alliance experience as a critical factor in selecting alliance partners in emerging countries (Hitt et al., 2000). As argued previously, from the social capital perspective the HTNV's attractiveness to potential foreign partners depends on what it can offer to them in return. In this sense our finding suggests that product development alliance formation may not only provide opportunities for the HTNVs to discover potential partners, but perhaps more importantly it indicates their reliability as alliance partners by providing signals as to the technical and marketing capabilities they have to offer.

Clearly, our findings indicate that the logic for HTNVs' adoption of agency business activity is multifaceted. Such an adoption is related to both 
the firm-specific and environmental inducements and opportunities available to it (Ahuja, 2000). Our study extends the literature into a new context: technology new ventures in a transitional economy.

In respect of the outcomes of agency business activity, our findings suggest a positive relationship between successful agency business activity and new venture performance. Given the crosssectional nature of our study, an alternative explanation that cannot be completely ruled out is that better performing HTNVs in China may be more likely to have a greater capability to be successful with agency business activity.

Contrary to our hypothesis, results indicate that successful agency business activity has a negative relationship with product innovation effort of the HTNVs. This finding appears contrary to the organizational learning perspective of alliance formation (Cohen and Levinthal, 1990; Kogut and Zander, 1992) and the organization slack view (Bourgeois, 1981; Cyert and March, 1963) that by adopting this strategy HTNVs may learn technical skills, thus contributing to their product innovations. Several reasons may account for this finding. First, successful agency business activity may divert the limited resources of the HTNVs away from their own technological innovation as they need to provide technological services to support the selling of the products of their alliance partners. As Rumelt (1974:1) argues, when a firm decides to enter another business, '. . . it is making a strategic decision whose consequences may alter the fundamental nature of the firm and may involve as well a substantial redeployment of resources and a redirection of human energy.' Second, a profitable agency business may lull managers of HTNVs into a false sense of security to the neglect of product innovation (Eisenhardt and Schoonhoven, 1996). Managers may consider that this activity is a less risky alternative growth strategy. For example, competences in the downstream activities involved in agency business activity as well as competencies in developing the associated network ties with foreign firms may be perceived as easier to negotiate and leverage than engaging in in-house product innovation. Third, it is possible that what HTNVs have learnt through this kind of downstream activities are marketing and sales techniques rather than technical skills, which may stifle product innovation. Finally, like all interorganizational strategies agency business activity may also be plagued by conflicts and other relationship problems between the parties in the alliance. Indeed, a study of technology ventures by Kotabe and Swan (1995) found no evidence to support a positive relationship between interorganizational relationships and product innovation.

Though not hypothesized, an interesting result from the study is that product development alliance has a significantly positive relationship with the HNTV's product innovation effort but a negative relationship with new venture performance. These findings are clearly in contrast to those obtained for successful agency business activity, indicating the difference between these two constructs. Unlike agency business activity, a product development alliance spans the entire product innovation process from design, development, to marketing. A plausible explanation for the positive relationship could be that a product development alliance may involve the transfer of technical as well as commercial skills from partners to the HTNV. These offer differential advantages to HTNVs in carrying out product innovation activities (Calantone, Schmidt, and Song, 1996). It is also possible that technical skills resident in a firm allow product innovation success, which permits greater success by the firm in attracting other companies for a product development alliance. However, a product development alliance may be negatively related to new venture performance because HTNVs may have a weaker position in the relationship. Thus it is difficult for HTNVs to generate benefits from such alliances. Admittedly, this explanation is speculative and warrants future study.

Previous research has argued that alliances with foreign firms appear to be an important route for firms to grow in a transitional economy (Peng and Heath, 1996; Zhao and Aram, 1995). This study advances this research stream by examining the factors that may be related to the adoption of agency business activity by HTNVs in China. The research presented here is part of a growing stream of strategic management literature investigating firm behavior in economic transitions (Bruton and Rubanik, 1997; Khanna and Palepu, 1997; Peng and Heath, 1996). Prior research has claimed that HTNVs should commit to a focus on product innovation (Eisenhardt and Schoonhoven, 1990; Feeser and Willard, 1990). Our study suggests that though product innovation is an important activity for HTNVs, agency business activity is an equally important strategy. 


\section{Managerial implications}

These findings have implications for managers. First, they suggest the need for managers to take a dual perspective of the internal and external factors facing the firms in alliance formation decisions. For example, firm resources could be a source of inducement as well as opportunity for HTNVs to enter into alliances. Yet, our results indicate that managers may not be taking full advantage of the resources available to compete in the alliance formation market. Whereas product development alliance appears to be a resource that provides opportunity for entry into alliance, the same opportunity that could be afforded by venture size (because of its implications of market presence and social networks) appears not to have been taken by firms in our sample. Further, managers of HTNVs view institutional support as alleviating resource limitations to the extent that their perception of the uncertain environment as an inducement and opportunity for alliance formation is reduced. From the opportunity-to-collaborate perspective, it could be suggested that institutional support could be used to build the HTNVs' internal resources and capabilities to make themselves attractive partners to potential alliance partners.

Another important implication is that although the successful agency business activity is positively related to a new venture's performance, it has a negative relationship with the new venture's product innovation activity. It may be argued that given the different goals and aspirations of HTNVs (Cyert and March, 1963; Kirchhoff, 1977), a focus on positive relationship of agency business activity with performance and its negative relationship with product innovation may be a conscious strategic choice made by management (Child, 1972) rather than a withering of skills. Although we are unable to determine which is the case, our results highlight the importance of managers being conscious of the potential dysfunctional implications of agency business activity for product innovations. This is important not only for effective goal setting for HTNVs but also for focusing their intentions and goals in negotiating and implementing such alliances.

\section{Limitations and future research}

Despite some contributions to the literature and practice, this study has limitations that should be addressed in future research. First, the crosssectional data used in the study do not allow for causal interpretations among the variables. For example, as mentioned previously, although we found that a successful agency business activity is positively related to new venture performance, it is also possible that better performance may precede successful agency business activity. Ideally the study would have benefited from a time lag between the measurement of the independent and dependent variables for causal relationships to be determined. However, as Kenny (1979) argued, a careful study of cross-sectional relationships before attempting to validate the findings via more costly time-lagged longitudinal studies is a commonly accepted approach for establishing causal relationships. We hope this study will serve as a foundation for such a study in the future.

Second, our theoretical model focuses on only a few internal and external factors. Other potentially relevant variables that merit consideration in the adoption of agency business activity are CEO or top management team characteristics such as size, previous experience, and social network relationships which several scholars suggest may influence alliance formation (Eisenhardt and Schoonhoven, 1990, 1996; Kraatz, 1998; Nahapiet and Ghoshal, 1998). In addition, other theoretical perspectives may also help explain HTNVs' tendency to adopt agency business activity. For instance, from a mimetic isomorphism point of view, HTNVs may economize on search costs and imitate the actions or strategies of other firms as a means of appearing legitimate (Schoonhoven, Eisenhardt, and Lyman, 1990). Thus, when some HTNVs adopt agency business activity and achieve better performance, this specific course of action becomes taken for granted and institutionalized. This theoretic perspective warrants research in the future.

Third, the constructs in the study were measured with self-reports. The use of retrospective data may pose such potential problems as limited recall of the respondents and biased perceptions of past realities. We took several measures during data collection to improve reliability and validity of retrospective reporting, including strengthening our analysis with more objective new venture performance data. However, this should not exclude the use of alternative methodologies in future research. In addition, our study 
is limited to the extent that the construct environmental uncertainty combines the informational and resource perspectives of the environment that may have different influences on firm decision making. However, we do not believe that this is a problem here as we found that environmental uncertainty and perceived industry growth (which clearly captures resource munificence in the environment) have differential relationships with adoption of agency business activity. Nevertheless, we call attention to the need for future research to differentiate and examine the resource and informational dimensions of environmental uncertainty. Further, the single-item measure of relatedness of agency business activity could be improved.

Finally, our sample has potential bias with half of the sample being in the electronic information industry. It may also be biased towards new ventures with greater chances of survival. Hence, we caution that our sample is not representative of new ventures in China or other economies. To enhance the generalizability of the findings, future research ought to build on these results and examine the adoption of agency business activity in other places in China and in other economies. In particular, a comparison of the alliance formation behavior of HTNVs in developed and transitional economies would shed useful light on the degree to which peculiarities of transitional economies such as underdevelopment of institutions have implications for alliance formations. Currently, the literature asserts that HTNVs in transitional economies face environmental conditions and significantly severer problems in obtaining capital and other resources than their counterparts in developed economies. For example, it has been argued that the underdevelopment of strategic factor markets makes it difficult for firms to raise capital and transfer assets and ownership in transitional economies such as China. Similarly, property rights are not clearly defined because of lack of an adequate legal framework. Government regulations are also very unpredictable, which creates more uncertainty and high costs for firms' growth (Peng and Heath, 1996). Scholars assert that these conditions make alliance formation a prime strategy for new ventures in transitional economies than in developed economies. Yet, there is little comparative empirical evidence to support such assertions. We hope future research would take on this line of inquiry.

\section{ACKNOWLEDGEMENTS}

We would like to thank Yan Zhang for her insightful comments on the earlier versions of this paper. We are grateful for financial support from the Hong Kong Government Competitive Earmarked Research Grant (No. 9040122) and Research Grant at Lingnan University in Hong Kong.

\section{REFERENCES}

Adler NJ, Campbell N, Laurent A. 1989. In search of appropriate methodology: from outside the People's Republic of China looking in. Journal of International Business Studies 20(1): 61-74.

Ahuja G. 2000. The duality of collaboration: inducements and opportunities in the formation of interfirm linkages. Strategic Management Journal 21(3): 317-343.

Anderson JC, Gerbing DW. 1988. Structural equation modeling in practice: a review and recommended twostep approach. Psychological Bulletin 103: 411-423.

Barney JB. 1991. Firm resources and sustained competitive advantage. Journal of Management 17: 99-120.

BHEZ Office. 1995. Zhongguo Beijing Xinjishu Chanye Kaifa Shiyanqu Yanjiu Baogao [Research Report on Beijing High Technology Experimental Zone (BHEZ) in China]. Beijing.

Bourgeois LJ III. 1981. On the measurement of organizational slack. Academy of Management Review 6(1): 29-39.

Bruton GD, Rubanik Y. 1997. High technology entrepreneurship in transitional economies: the Russian experience. Journal of High Technology Management Research 8(2): 213-223.

Bucklin LP, Sengupta S. 1993. Organizing successful comarketing alliances. Journal of Marketing 57(April): $32-46$.

Calantone RJ, Schmidt JB, Song XM. 1996. Controllable factors of new product success: a cross-national comparison. Marketing Science 15(4): 341-358.

Child J. 1972. Organizational structure, environment and performance: the role of strategic choice. Sociology 6: $1-22$.

China Economic News. 2000. Implications of Yuxing Infotech's listing in Hong Kong. 21 February: 6-7.

Cohen WM, Levinthal DA. 1990. Absorptive capacity: a new perspective on learning and innovation. Administrative Science Quarterly 35: 128-152.

Conant JS, Mokwa MP, Varadarajan PR. 1990. Strategic types, distinctive marketing competencies and organizational performance: a multiple measures-based study. Strategic Management Journal 11(5): 365-383.

Cyert RM, March JG. 1963. A Behavioral Theory of Firm. Prentice-Hall: Englewood Cliffs, NJ. 
Dess GG, Beard DW. 1984. Dimensions of organizational task environments. Administrative Science Quarterly 29: 52-73.

Dess GG, Robinson RB. 1984. Measuring organizational performance in the absence of objective measures. Strategic Management Journal 5(3): 265-273.

Dickson PH, Weaver KM. 1997. Environmental determinants and individual-level moderators of alliance use. Academy of Management Journal 40(2): 404-425.

Dowling MJ, McGee JE. 1994. Business and technology strategies and new venture performance: a study of the telecommunications equipment industry. Management Science 40(12): 1663-1677.

Downey H, Hellriegel D, Slocum J. 1975. Environmental uncertainty: the construct and its application. Administrative Science Quarterly 20: 613-629.

Dyer JH, Singh H. 1998. The relational view: cooperative strategy and sources of international competitive advantage. Academy of Management Review 23(4): 660-679.

Eisenhardt KM, Schoonhoven CB. 1990. Organizational growth: linking founding team, strategy, environment, and growth among U.S. semiconductor ventures, 1978-1988. Administrative Science Quarterly 35(3): 504-529.

Eisenhardt KM, Schoonhoven CB. 1996. Resource-based view of strategic alliance formation: strategic and social effects in entrepreneurial firms. Organization Science 7(2): 136-150.

Feeser HR, Willard GE. 1990. Founder strategy and performance: a comparison of high and low growth high tech firms. Strategic Management Journal 11(2): 87-98.

Geringer JM, Hebert L. 1991. Measuring performance of international joint ventures. Journal of International Business Studies 22(2): 249-264.

Granovetter MS. 1985. Economic action and social structure: the problem of embeddedness. American Journal of Sociology 78: 1360-1380.

Grenadier SR, Weiss AM. 1997. Investment in technological innovations: an option pricing approach. Journal of Financial Economics 44: 397-416.

Gulati R. 1995. Does familiarity breed trust? The implications of repeated ties for contractual choice in alliances. Academy of Management Journal 38: $85-112$.

Gulati R. 1998. Alliances and networks. Strategic Management Journal 19(4): 293-317.

Gulati R. 1999. Network location and learning: the influence of network resources and firm capabilities on alliance formation. Strategic Management Journal 20(5): 397-420.

Hagedoorn J, Schakenraad J. 1994. The effect of strategic technology alliances on company performance. Strategic Management Journal 15(4): 291-309.

Hannan MT, Freeman J. 1977. The population ecology of organizations. American Journal of Sociology 82(4): 929-964.

Hitt MA, Dacin T, Levitas E, Arregle JL, Borza A. 2000. Partner selection in emerging and developed market contexts: resource-based and organizational learning perspectives. Academy of Management Journal 43(3): 449-467.

Hoskisson RE, Eden L, Lau CM, Wright M. 2000. Strategy in emerging economies. Academy of Management Journal 43(3): 249-267.

Kenny DA. 1979. Correlation and Causality. Wiley: New York.

Khanna T, Palepu K. 1997. Why focused strategies may be wrong for emerging markets. Harvard Business Review 75(4): 41-51.

Kirchhoff BA. 1977. Organization effectiveness measurement and policy research. Academy of Management Review 2(3): 347-355.

Kogut B. 1988. Joint ventures: theoretical and empirical perspectives. Strategic Management Journal 9(4): 319-332.

Kogut B, Zander U. 1992. Knowledge of the firms, combinative capabilities and the replication of knowledge. Organization Science 3: 383-397.

Kotabe M, Swan KS. 1995. The role of strategic alliances in high technology new product development. Strategic Management Journal 16(8): 621-636.

Kraatz MS. 1998. Learning by association? International networks and adaptation to environmental change. Academy of Management Journal 41(6): 621-643.

Lane PJ, Lubatkin M. 1998. Relative absorptive capacity and interorganizational learning. Strategic Management Journal 19(5): 461-477.

MacMillan IC, Siegel R, Narasimha RNS. 1985. Criteria used by venture capitalists to evaluate new venture proposals. Journal of Business Venturing 1(1): 87-105.

Magrath AJ. 1992. The 6 Imperatives of Marketing: Lessons from the World's Best Companies. American Management Association: New York.

McCann JE. 1991. Patterns of growth, competitive technology, and financial strategies in young firms. Journal of Business Venturing 6(3): 189-203.

McDougall PP, Covin JG, Robinson RB Jr, Herron L. 1994. The effects of industry growth and strategic breadth on new venture performance and strategy content. Strategic Management Journal 15(7): 537-554.

McDougall PP, Robinson RB Jr. 1990. New venture strategies: an empirical identification of eight 'archetypes' of competitive strategies of entry. Strategic Management Journal 11(6): 447-467.

Miller D. 1987. The structural and environmental correlates of business strategy. Strategic Management Journal 7(3): 233-249.

Miller A, Camp B. 1985. Exploring determinants of success in corporate ventures. Journal of Business Venturing 1(1): 87-105.

Miller CC, Cardinal LB, Glick WH. 1997. Retrospective reports in organizational research: a reexamination of recent evidence. Academy of Management Journal 40(1): 189-204.

Nahapiet J, Ghoshal S. 1998. Social capital, intellectual capital, and the organizational advantage. Academy of Management Review 23(2): 242-266.

Nee V. 1989. A theory of market transition: from redistribution to markets in state socialism. American Sociological Review 54(October): 663-681. 
North DC. 1990. Institutions, Institutional Change and Economic Performance. Harvard University Press: Cambridge, MA.

O'Shea M, Stevens C. 1998. Governments as venture capitalists. OECD Observer 213(August/September): $26-29$.

Pearce JA. 1983. The relationship of internal versus external orientations to financial measures of strategic performance. Strategic Management Journal 4(4): 297-306.

Peng MW, Heath PS. 1996. The growth of the firm in planned economies in transition: institutions, organizations, and strategic choice. Academy of Management Review 21(2): 492-528.

Pfeffer J, Salancik GR. 1978. The External Control of Organizations. Harper \& Row: New York.

Phillips LW. 1981. Assessing measurement error in key informant reports: a methodological note on organizational analysis in marketing. Journal of Marketing Research 18(November): 395-415.

Porter ME. 1980. Competitive Strategy. Free Press: New York.

Powell WW, Brantley P. 1992. Competitive cooperation in biotechnology: learning through networks. In Networks and Organizations: Structure, Form and Action, Nohria N, Eccles R (eds). Harvard Business School Press: Boston, MA; 366-394.

Powell WW, Koput K, Smith-Doerr L. 1996. Interorganizational collaboration and the locus of innovation: networks of learning in biotechnology. Administrative Science Quarterly 41: 116-145.

Rumelt RP. 1974. Strategy, Structure, and Economic Performance. Harvard Business School Press: Boston, MA.

Sandberg WR, Hofer CW. 1987. Improving new venture performance: the role of strategy, industry structure, and the entrepreneur. Journal of Business Venturing 2(1): 5-28.

Schoonhoven CB, Eisenhardt KM, Lyman K. 1990. Speeding products to markets: waiting time to first product introductions in new firms. Administrative Science Quarterly 35(1): 177-207.
Shan W. 1990. An empirical analysis of organizational strategies by entrepreneurial high-technology firms. Strategic Management Journal 11(2): 129-139.

Shan W, Walker G, Kogut B. 1994. Interfirm cooperation and startup innovation in the biotechnology industry. Strategic Management Journal 15(5): 387-394.

Simerly RL, Li M. 2000. Environmental dynamism, capital structure and performance: a theoretical integration and an empirical test. Strategic Management Journal 21(1): $31-49$.

Stinchcombe AL. 1965. Organizations and social structure. In Handbook of Organizations, March JG (ed.). Rand McNally: Chicago, IL; 142-193.

Stuart TE. 1998. Network positions and propensities to collaborate: an investigation of strategic alliance formation in a high-technology industry. Administrative Science Quarterly 43: 668-698.

Stuart TE. 2000. Interorganizational alliances and the performance of firms: a study of growth and innovation rates in a high-technology firms. Strategic Management Journal 21(8): 791-811.

Stuart TE, Hoang H, Hybels RC. 1999. Interorganizational endorsements and the performance of entrepreneurial ventures. Administrative Science Quarterly 44: 315-349.

Teece DJ. 1980. Economics of scope and the scope of the enterprise. Journal of Economic Behavior and Organization 1: 223-247.

Varadarajan PR, Cunningham MH. 1995. Strategic alliances: a synthesis of conceptual foundations. Journal of the Academy of Marketing Science 23(4): 282-296.

Zahra SA. 1993. Environment, corporate entrepreneurship and financial performance: a taxonomic approach. Journal of Business Venturing 8(4): 319-340.

Zahra SA, Covin JG. 1993. Business strategy, technology policy, and company performance. Strategic Management Journal 14(6): 451-478.

Zhao L, Aram JD. 1995. Networking and growth of young technology-intensive ventures in China. Journal of Business Venturing 10(5): 349-370. 